\title{
The Contribution of Forests and Trees to Sustainable Diets
}

\author{
Barbara Vinceti ${ }^{1, *}$, Céline Termote ${ }^{1}$, Amy Ickowitz ${ }^{2}$, Bronwen Powell ${ }^{2}$, Katja Kehlenbeck ${ }^{3}$ \\ and Danny Hunter ${ }^{1,4}$
}

1 Bioversity International, via dei Tre Denari 472/a, 00057 Maccarese, Rome, Italy;

E-Mails: c.termote@cgiar.org (C.T.); d.hunter@cgiar.org (D.H.)

2 Center for International Forestry Research (CIFOR), Jalan CIFOR, Situ Gede, Bogor (Barat) 16115, Indonesia; E-Mails: a.ickowitz@cgiar.org (A.I.); b.powell@cgiar.org (B.P.)

3 World Agroforestry Centre (ICRAF), United Nations Avenue, P. O. Box 30677, Nairobi 00100, Kenya; E-Mail: k.kehlenbeck@cgiar.org

4 Charles Sturt University, Orange, New South Wales 2678, Australia

* Author to whom correspondence should be addressed; E-Mail: b.vinceti@cgiar.org; Tel.: +39-06-6118-412; Fax: +39-06-6197-9661.

Received: 10 September 2013; in revised form: 29 October 2013 / Accepted: 31 October 2013 / Published: 11 November 2013

\begin{abstract}
With the growing demands from a population expected to reach 9 billion people by 2050 , it is unclear how our current global food system will meet future food needs. Ensuring that all people have access to adequate and nutritious food produced in an environmentally and socio-culturally sustainable manner is one of the greatest challenges of our time. "Sustainable diets" have been proposed as a multidimensional framework to address the need for nutritious and adequate food in the context of the many challenges facing the world today: reducing poverty and hunger, improving environmental health, enhancing human well-being and health, and strengthening local food networks, sustainable livelihoods and cultural heritage. This paper examines the contribution of forests and trees to sustainable diets, covering among others, nutritional, cultural, environmental and provisioning aspects. The literature reviewed highlight major opportunities to strengthen the contribution of forest and tree foods to sustainable diets. However, several constraints need to be removed. They relate to: cultural aspects, sustainable use of non-wood forest products, organization of forest food provisioning, limited knowledge of forest food composition, challenges in adapting management of forests and trees to account for forest foods, and in integrating forest biodiversity into complex landscapes managed for multiple benefits. Finally, the paper identifies research
\end{abstract}


gaps and makes recommendations to enhance the contribution of forest foods to sustainable diets through increased awareness and better integration of information and knowledge on nutritious forest foods into national nutrition strategies and programs.

Keywords: forest foods; food security; sustainable diets; nutrition-sensitive value chains; biodiversity; nutrition

\section{Introduction}

It is unclear how the current global food system will meet the growing demands of a population expected to reach 9 billion people by 2050. In the present context of climate change, ongoing loss of species and genetic diversity, soil degradation, increasing urbanization, social conflict and extreme poverty, there is an urgent need for collective action to address food and nutrition security at the global level [1].

Energy-rich staple crops assure caloric adequacy, and policymakers have historically made them a focus in the quest for global food security. However, staples, generally derived from cereal, starchy tuber and root vegetables, contain small quantities of limiting nutrients per unit of energy, and by themselves are not sufficient to address the problem of "hidden hunger" or micronutrient deficiency [2,3]. Increasing consumption of micronutrient-dense foods (such as a diversity of fruit, pulses, vegetables and some animal source foods) is seen as a viable, cost-effective and sustainable way to improve nutrient quality and diets [2-4]; food-based solutions address the multiple dimensions of food production and consumption, such as social, economic, environmental and health aspects. In this context, the challenges are to make food systems simultaneously environmentally and economically sustainable, nutrition-sensitive, and culturally acceptable [5]. In addition, consumers and producers should have the necessary information to make the best choices taking into account also dietary requirements.

\subsection{Forest Ecosystems and Agroforestry}

Forests play an important role in many food systems, either through direct and indirect provisioning for human nutrition, particularly in developing countries [6-10], and through ecosystem services [11]. Forests and trees-outside-forests contribute to the livelihoods of more than 1.6 billion people [12]. Forests range from closed to open formations and cover 31\% (4 billion hectares) of total land area [12]. This calculation is based on FAO's definition of forest as a piece of land of more than 0.5 hectares, with more than $10 \%$ tree crown cover (or equivalent stocking level) and trees reaching a minimum height of 5 meters at maturity in situ [13]. Agroforestry is a series of land management approaches that integrate annual crop cultivation, livestock production and other farm activities with trees in small patches (often not larger than 0.5 hectares) scattered across densely populated agricultural landscapes.

Around $30 \%$ of the world's forests are used primarily for production of wood and non-wood forest products (NWFPs). These consist of goods of biological origin other than timber and fuelwood, derived from forests, other wooded land and trees outside forests. According to the most recent Global Forest Resource Assessment [12], the estimated value of NWFPs extracted in 2005, based on available country reports, amounts to approximately US\$ 18.5 billion, with food products as the highest 
estimated value among the ten most reported categories for NWFPs. China accounted for the largest amount of NWFPs extracted for food production, with major NWFPs including food and oil (e.g., bamboo shoots, chestnuts, walnuts, jujube, gingko, tea-oil); other food products were forest drinks, edible fungi, and mountain-grown edible wild herbs [14]. However, information on NWFPs is not available for many countries. Their true subsistence value is not captured by available statistics, therefore the data reported are most likely an underestimate.

\subsection{Sustainable Diets}

The first International Scientific Symposium on Biodiversity and Sustainable Diets, held at FAO in 2010, defined sustainable diets as:

Those diets with low environmental impacts which contribute to food and nutrition security and to healthy life for present and future generations. Sustainable diets are protective and respectful of biodiversity and ecosystems, culturally acceptable, accessible, economically fair and affordable; nutritionally adequate, safe and healthy; while optimizing natural and human resources [15].

Research on what constitutes a sustainable diet, and how to promote it, is still at an early stage and more research is needed to fully capture its many dimensions (Figure 1). What is particularly challenging is the operationalization of the concept of sustainable diets into measurable, robust and useful metrics or indicators. This could allow for comparison of diets across regions and countries and guide future policies and programs [16].

There are currently no precise and reliable global common metrics in use to measure the sustainability of a given food, diet or food system. Bioversity International, with the support of La Fondation Daniel et Nina Carasso and the CGIAR research program on Agriculture for Nutrition and Health (A4NH) is undertaking new and innovative research on describing, measuring and promoting sustainable diets. A comprehensive review of scientific studies and initiatives describing and measuring dimensions of sustainable diets and food systems has been undertaken. Currently, work is ongoing to develop a coherent framework and to identify a consensus-based methodology to select appropriate indicators. Two main partners are the FAO Nutrition and Consumer Protection Division, and CIHEAM (Mediterranean Agronomic Institute of Montpellier). Associate experts from the University of Aberdeen, City University London, Columbia University, IDS-Sussex, INRA, IRD, McGill University, SupAgro, Tufts University are involved.

Future work on sustainable diets should not neglect the role and contribution of forests and trees. This paper examines the contribution of forest ecosystems (including shrubs, wild edible plants and bushmeat) and trees outside forests to the dimensions of sustainable diets, presented in Figure 1.

The dimensions of sustainable diets have been regrouped for easiness of presentation around the following aspects of forest foods: (1) availability and accessibility of local, affordable forest foods and their contribution to food security; (2) nutritional quality; (3) cultural importance; (4) marketing (including indirect benefits from NWFPs in the form of income), value-chains (nutrition-sensitive); and (5) environmental aspects. 
Figure 1. The many dimensions of a sustainable diet. (Source: FAO/Bioversity [15].)

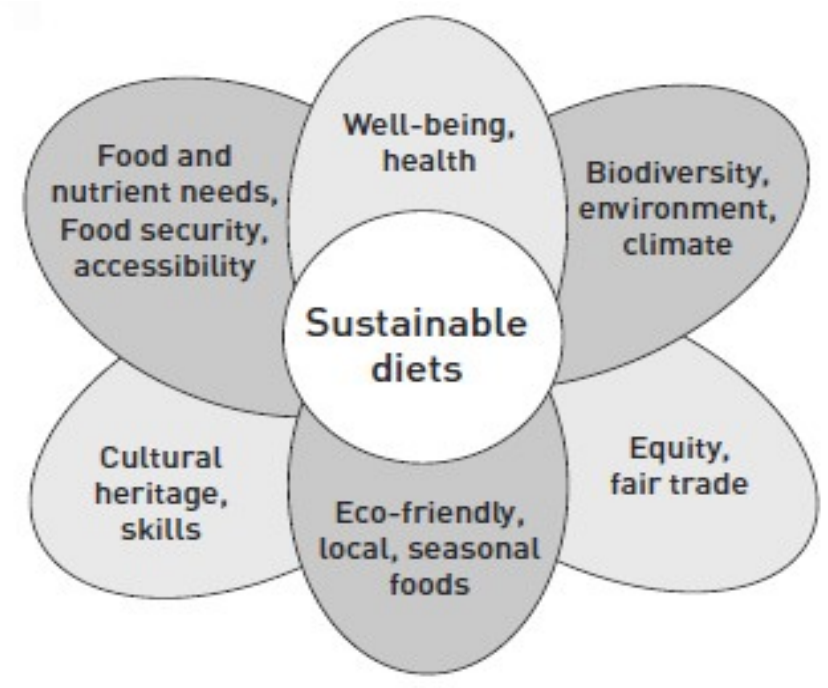

\section{Forest Foods and Sustainable Diets}

This section reviews the main characteristics of forest foods and the ways in which they relate to the main dimensions of the sustainable diet framework. A bibliographic review was carried out. A list of search terms in English was used to screen the literature, using different combinations of the following key words: sustainable diet, forest food, nutrition, food security, value chain, NWFPs. The search terms were applied to identify literature that incorporated one or more key words in a significant way, using Web of Science, Google Scholar and Scirus. The key themes analyzed were the nutritional properties of forest foods and their contribution to food security. The literature search identified a total of 561 relevant studies. Expert knowledge was used in order to filter and select the results, ensuring balanced coverage of different regional contexts and disciplines (forestry, agroforesty, nutrition, socioeconomic and livelihood studies), giving priority to recent articles and overview papers.

\subsection{Availability and Accessibility of Local, Affordable Forest Foods}

Forest foods, including products from trees, herbs, mushrooms and animals, contribute in many ways to improving food security by providing ready accessibility to affordable and often highly nutritious food $[8,17,18]$. While there are very few communities in the world that currently rely on forest foods to provide a complete diet [19,20], forest foods can supply many essential micronutrients. They can help contribute to caloric intake during lean season (complementing for example the seasonality of staple agricultural crops) and at times of low agricultural production due to various shocks [21-23]. Forest products can also be sold in times of crisis to earn the income needed to ensure food security [24]. Combining a "portfolio" of different indigenous fruit tree species for cultivation in agroforestry systems, based on the seasonal calendar of fruit harvest times, could result in a year-round supply of key nutrients (see Table 1) [7].

Forest foods should not be viewed as a panacea for global issues related to food security and nutrition, but in some specific geographic contexts they can have a significant role. Despite their value and contribution to the "global food basket", wild foods only recently made an appearance in official 
statistics on the economic value of natural resources. These data come mainly from the informal sector, and questions remain about their reliability. Detailed inventories of forest foods exist only for specific sites and the literature is scattered [8,9,25-27]. Global estimates need to be considered with caution because they include data from very different contexts and are collected using different methodological approaches [28], so there is a wide margin for improvement in the process of documenting the consumption of wild foods.

Table 1. A harvest calendar of indigenous fruit tree species from Southern Africa (months when fruits are ready for harvest are shaded in grey) useful to develop a fruit tree 'portfolio' that would allow continuous availability of ripe fruits from at least two species each month. The combination could be also designed to meet specific nutrient requirements. (Source: modified from Jamnadass et al. [7].)

\begin{tabular}{|l|l|l|l|l|l|l|l|l|l|l|l|l|}
\hline \multicolumn{1}{|c|}{ Tree Species } & \multicolumn{9}{|c|}{ Months } \\
\hline & Jan & Feb & Mar & Apr & May & Jun & Jul & Aug & Sep & Oct & Nov & Dec \\
\hline Uapaca kirkiana & & & & & & & & & & & & \\
\hline Azanza garckeana & & & & & & & & & & & & \\
\hline Flacourtia indica & & & & & & & & & & & & \\
\hline Vangueria infausta & & & & & & & & & & & & \\
\hline Vitex doniana & & & & & & & & & & & & \\
\hline Adansonia digitata & & & & & & & & & & & & \\
\hline Ziziphus mauritiana & & & & & & & & & & & & \\
\hline Parinari curatellifolia & & & & & & & & & & & & \\
\hline Strychnos cocculoides & & & & & & & & & & & & \\
\hline
\end{tabular}

\subsection{Nutritional Quality of Forest Foods}

From a nutritional perspective, forests and trees offer sources of many micronutrients commonly lacking from diets in developing countries and which have important health and developmental functions [29]. For example, vitamin A plays a key role for proper immune function [30,31]; deficiency causes blindness in up to 500,000 children every year and is associated with higher rates of infection (diarrhea, measles, respiratory tract infections, etc.). Good dietary sources of vitamin A are green leafy vegetables and orange-colored fruit and vegetables [32,33]. Iron, zinc and vitamin $\mathrm{B}_{12}$ deficiencies can impair growth, cognitive development and school performance, with life-long implications for health and socio-economic success [29]. The best dietary sources of these nutrients are animal source foods (bushmeat), leafy green vegetables commonly collected in forest areas [34-36], and legumes.

"Bushmeat", or wild meat, constitutes the main source of animal protein in many tropical forested landscapes, especially in the Congo and Amazon basin [9]. It includes non-domesticated terrestrial mammals, birds, reptiles and amphibians harvested for food by humans, with the larger vertebrates representing the majority of the terrestrial wild animal biomass consumed [37]. Animal source foods, such as bushmeat, are the only dietary source of vitamin $\mathrm{B}_{12}$, vitamin $\mathrm{D}$, and highly bioavailable iron and retinol $[38,39]$. A recent study from Madagascar estimated that the loss of bushmeat from the diet 
of children, without substitution with other foods, would result in a $29 \%$ increase in children suffering from iron deficiency anemia [40].

Even though the nature of the evidence is still circumstantial, many authors find that there is a reasonable and compelling case to argue that access to and use of biological diversity from both forests and farm land leads to a more varied diet $[4,41,42]$, which in turn improves health outcomes $[43,44]$. A study by Powell et al. [18] in the East Usambara Mountains (Tanzania), showed that $48 \%$ of the food species consumed could be obtained in forest ecosystems (Figure 2), and children who had used forest foods had diets with higher diversity and nutrient density, and consumed a larger number of animal source food items.

Figure 2. Total number of wild species from the forest and other land use types consumed by 270 surveyed households, grouped by different food types (East Usambara Mountains, Tanzania). (Source: Powell et al. [18].)

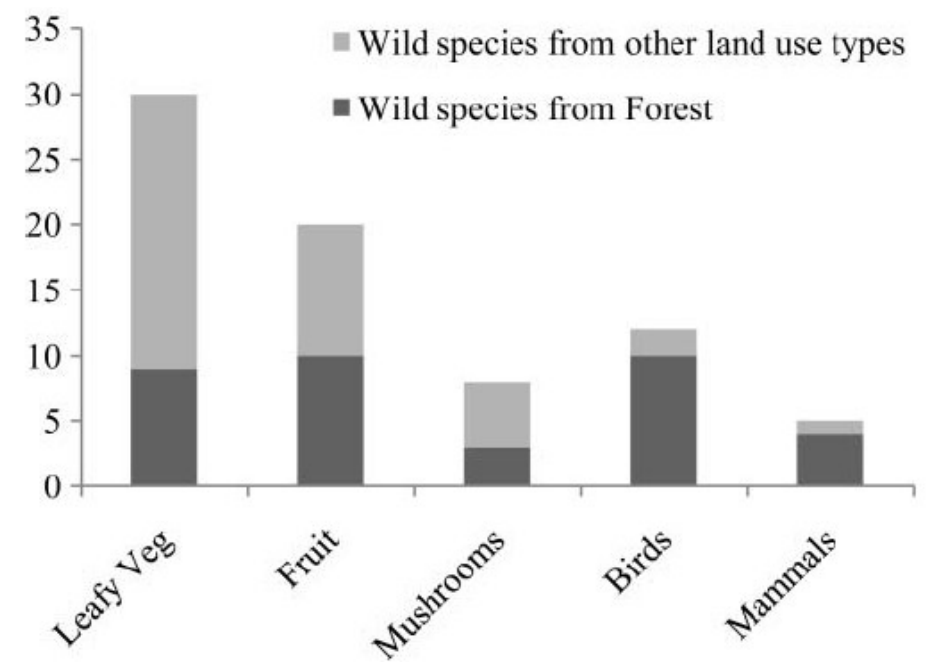

It has been estimated that between $48 \%$ and $68 \%$ of the population in sub-Saharan Africa suffer from some form of malnutrition [45]. Iron and vitamin A deficiency are among the most common forms of undernutrition in this region. Fruit consumption in sub-Saharan Africa has been estimated to fall considerably short of the recommended daily amount [46]. And yet, a number of indigenous fruit have a high vitamin and mineral content and the potential to contribute to the micronutrient supply of local communities (Table 2) [47]. For example, consuming 40-100 g of berries from Grewia tenax (Forrsk.) Fiori (a fruit-producing deciduous shrub or small tree of widespread occurrence in semi-arid and sub-humid tropical climates in Africa, the Arabian Peninsula, and Asia) could supply almost 100\% of the daily iron requirement of a child under 8 years of age. In addition to micronutrients, the high sugar content of fruits such as tamarind (Tamarindus indica L.) and baobab (Adansonia digitata L.) make them important sources of energy (Table 2). Likewise, the fruits of Dacryodes edulis (G.Don) H.J.Lam, and the seeds of Irvingia gabonensis (Aubrey-Lecomte ex O'Rorke) Baill., Sclerocarya birrea (A. Rich.) Hochst. and Vitellaria paradoxa C.F. Gaertn. have high fat contents (respectively 32, 67, 57 and 46 g per 100 g edible portion), comparable with, or even higher than peanuts (Arachis hypogaea L.; 46 g per 100 g) [48,49]. 
Table 2. Nutrient content of selected African indigenous and exotic fruits per $100 \mathrm{~g}$ edible portion (relatively high values are highlighted in bold). $\mathrm{RE}=$ retinol equivalents. (Source: Kehlenbeck et al. [47], Stadlmayr et al. [49], and Stadlmayr et al. [50].)

\begin{tabular}{|c|c|c|c|c|c|c|}
\hline Species & $\begin{array}{c}\text { Energy } \\
\text { (Kcal) }\end{array}$ & $\begin{array}{c}\text { Protein } \\
\text { (g) }\end{array}$ & $\begin{array}{l}\text { Vit C } \\
\text { (mg) }\end{array}$ & $\begin{array}{c}\text { Vit A (RE) } \\
(\mu \mathrm{g})\end{array}$ & $\begin{array}{l}\text { Iron } \\
\text { (mg) }\end{array}$ & $\begin{array}{c}\text { Calcium } \\
\text { (mg) }\end{array}$ \\
\hline \multicolumn{7}{|l|}{ Indigenous fruits: } \\
\hline Adansonia digitata $\mathrm{L}$. & 327 & 2.5 & $126-509$ & $0.03-0.06$ & 6.2 & 275 \\
\hline Grewia tenax (Forrsk.) Fiori & N.A. & 3.6 & N.A. & N.A. & 7.4-20.8 & 610 \\
\hline Sclerocarya birrea Hochst. & 225 & 0.7 & $85-319$ & 0.035 & 3.4 & 35 \\
\hline Tamarindus indica L. & 275 & 3.6 & $11-20$ & $0.01-0.06$ & 3.1 & 192 \\
\hline Ziziphus mauritiana Lam. & 184 & 0.4 & $3-14$ & 0.07 & 0.8 & 23 \\
\hline \multicolumn{7}{|l|}{ Exotic fruits: } \\
\hline Guava (Psidium guajava L.) & 68 & 2.6 & 228.3 & 0.031 & 0.3 & 18 \\
\hline Mango (Mangifera indica L.) & 65 & 0.5 & 27.7 & 0.038 & 0.1 & 10 \\
\hline Orange (Citrus sinensis L. Osbeck) & 47 & 0.9 & 53.0 & 0.008 & 0.1 & 40 \\
\hline Pawpaw (Carica papaya L.) & 39 & 0.6 & 62.0 & 0.135 & 0.1 & 24 \\
\hline
\end{tabular}

For what concerns the quality of the information on forest food composition, Colfer et al. caution that data on the nutrient content of many indigenous fruits are still either unavailable or unreliable [51]. Until a decade ago, there was little research available on the range and origin of intraspecific genetic variation behind variable nutritive values and other horticultural properties, such as fruit size, pulp proportion or yield of edible products from key indigenous tree species [48]. Recently, some studies on the variation of nutritional properties of indigenous tree species have become available, e.g., for Canarium indicum L. nuts [52], peach palm (Bactris gasipaes Kunth.) fruits [53], and marula (Sclerocarya birrea Hochst.) fruits and seeds [54]. Wide variability in desirable traits, such as fruit size, vitamin content, oil composition or pulp proportion, is an essential prerequisite for breeding and domestication, and provides an excellent opportunity to develop cultivars from phenotypically superior trees that have been shown, through progeny testing, to produce superior offspring [55]. Genetic diversity in crop wild relatives, including tree species, can also enable bio-fortification (breeding aimed at increasing the nutritional value) [41].

Domestication programs are now being developed to bring many wild tree species into cultivation and integrate them into agroforestry systems. Examples of such species include Adansonia digitata L., different Allanblackia spp., Barringtonia procera (Miers) R.Knuth, Canarium indicum L., Dacryodes edulis (G.Don) H.J.Lam, Gnetum africanum Welw., Irvingia gabonensis (Aubrey-Lecomte ex O’Rorke) Baill., Sclerocarya birrea Hochst., Uapaca kirkiana Müll.Arg. and Vitellaria paradoxa C.F. Gaertn. [27].

\subsection{Cultural Importance of Forest Foods}

In most societies that traditionally inhabit areas with significant forest cover, forest foods have been used for generations and many have social and cultural importance. Wild edible plants are part of the intangible cultural heritage of local populations [56] and can be related to cultural identity [57-59]. 
Knowledge about the identification, preparation and sustainable management of forest and wild foods is part of indigenous knowledge systems and practices that have been developed over many generations. These can play an important part in decision-making with respect to local food production, human and animal health, and management of natural resources [60]. In South Africa, most forest foods traded in local markets maintain a key position in local culture; in several cases commercial substitutes of forest foods do not exist, and wild resources are generally preferred even when alternative products can be found [61]. Extensive reviews of indigenous food systems by Kuhnlein et al. including a range of NWFPs, highlight both their nutritional and cultural importance [62,63].

Food culture and preferences affect local markets. In Asian countries, most households rely on traditional retailers for fruits and vegetables because supermarkets often have a limited range of products [64]. Wong [65] reported that most of the production of tropical fruits in Sabah and Sarawak (Malaysia), and South Kalimantan (Indonesia), comes from home gardens (refer to Section 3.6 for definition). In these areas, community forests supply forest foods, contribute to sustainable diets and have a high cultural value. About $15 \%-20 \%$ of the trees growing in community forests are fruit tree species such as durian, breadfruits, rambutan, mangosteen and wild species of Mangifera. In addition, the forests are sources of wild and uncultivated vegetables, spices, nuts, honey and medicines.

In Kota Belud (Sabah), a site inhabited by the Illanuns, Bajau and Kadazandusun indigenous ethnic groups, the Mangifera species have unique uses. For example, fruits of M. odorata (Kwini, Wani) and M. caesia (Binjai, Beluno) are used for fresh consumption, while M. pajang (Bambangan) is mainly processed into pickle on its own or with fish. The first flush of young leaves after the rainy season are used like a vegetable and cooked with freshwater fish [66]. The fruits can be used for producing juice, sweets and jam. From the analysis of local Mangifera diversity and associated traditional knowledge (refer to Section 3.1 for definition) available in Sabah, one can draw insights into the potential opportunities for value addition and income generation based upon locally available biodiversity. Several examples of value chain development exist for products from species within the genera Garcinia, Nephelium and Citrus, in India, Indonesia, and Thailand [67].

\subsection{Marketing and Value Chains Integrating Forest Foods}

NWFPs can contribute indirectly to food security and nutritional outcomes through the income generated by their sale. Efforts to understand the role of NWFPs have increasingly moved away from isolated case studies to global analyses based on uniform criteria, so as to draw lessons at a broader scale [68,69] across regions [70] or regarding different products [71]. Results suggest that forest foods contribute to income and poverty reduction, and that wild harvested plants and animals are of particular importance to the economy of the world's rural poor, particularly for forest communities [72-74]. The collection and sale of wild foods can provide considerable support especially for those who lack the capital to engage in other livelihood activities (women and the most disadvantaged members of a community) $[61,70,75,76]$.

Locally important forest products contribute significantly to livelihoods not only for rural people, but also in urban and peri-urban environments where intermediaries and traders of NWFPs often come from poorer and more marginalized sectors of society [77-79]. In many cases, traders carry out useful marketing functions such as risk taking and transport, which can be costly. They play a pivotal role 
that enables farmer-gatherers to increase the value of the NWFPs in their environment thereby increasing the incentives for forest conservation [80].

The increasing orientation of agricultural policies towards markets means that a larger number of farmers are net food buyers, with markets playing a more significant role in determining food availability and access, a role strengthened by urbanization [81,82]. A value chain approach examines how value is added to a particular product along the chain of processes involving different actors, from the place of production to consumption. The development of a nutrition-sensitive value chains takes into considerations diet quality and nutrition and focuses on improving supply of and demand for foods that are rich in essential micronutrients (e.g., fruits and vegetables, meat, fish, etc.), as a way to address malnutrition [83].

An example is provided for a very important food tree species in Melanesia, Canarium indicum var. indicum, a large tree native of Indonesia, Papua New Guinea, the Solomon Islands and Vanuatu, regarded as well suited to community forestry and mixed arboricultural systems. It is also a very important food and ceremonial tree, whose nuts have interesting nutritional properties (see Table 3). The species has great, untapped commercial potential, mainly due to its abundance and the production of non-perishable nuts-in-shell, which can be transported easily, stored for long periods of time, and do not have the challenges of a temperature-controlled supply chain. The trade in Canarium nuts is predominantly based on wild and garden tree populations [84].

Table 3. The food composition per $100 \mathrm{~g}$ of raw Canarium indicum L. nut.

\begin{tabular}{cccccccc}
\hline Nutrient & Content & Nutrient & Content & Nutrient & Content & Nutrient & Content \\
\hline Water $(\mathrm{g})$ & 35.4 & Protein $(\mathrm{g})$ & 8.2 & Fat $(\mathrm{g})$ & 45.9 & Sugar $(\mathrm{g})$ & 0.2 \\
Starch $(\mathrm{g})$ & 0.3 & Ash $(\mathrm{g})$ & 2.6 & Fiber & 10.6 & $\beta$-car. Eq. $(\mu \mathrm{g})$ & 165 \\
Vit. C $(\mathrm{mg})$ & 8 & Thiamin $(\mathrm{mg})$ & 0.13 & Riboflavin & 0.06 & Niacin $(\mathrm{mg})$ & 1.7 \\
$\mathrm{Fe}(\mathrm{mg})$ & 3.5 & $\mathrm{Na}(\mathrm{mg})$ & 18 & $\mathrm{~K}(\mathrm{mg})$ & 627 & $\mathrm{Ca}(\mathrm{mg})$ & 44 \\
$\mathrm{Mn}(\mathrm{mg})$ & 1.1 & $\mathrm{Mg}(\mathrm{mg})$ & 284 & $\mathrm{Zn}(\mathrm{mg})$ & 2.4 & $\mathrm{Cu}(\mathrm{mg})$ & 1.6 \\
& & Edible portion $(*)$ & $13 \%$ & Energy & $439 \mathrm{kcal} / 1838 \mathrm{~kJ}$ & & \\
\hline
\end{tabular}

(*) Table 2. The inedible material is the hard shell of the nut. (Source: English et al. [85].)

The Canarium nut industry is still in its infancy in the Pacific but the demand for processed Canarium nuts on the domestic market exceeds supply so there is the potential to use this as a platform for expanding both export and domestic markets. The value chain differs across producing countries, with more advanced value adding in Vanuatu compared to Solomon Island and Papua New Guinea. The figure below depicts graphically the value chain in Vanuatu (Figure 3). Solid arrows indicate a larger flow.

The diagram represents a snapshot in time as the situation is continuously changing, especially in an emerging industry. The airline sector represents a potential market, not yet developed. Several small processors are getting started in the industry but only just beginning to supply the product to the market. 
Figure 3. Industry-wide value chain map for Canarium indicum L. in Vanuatu. (Source: AIARC [86]; Thomson and Evans [87].)

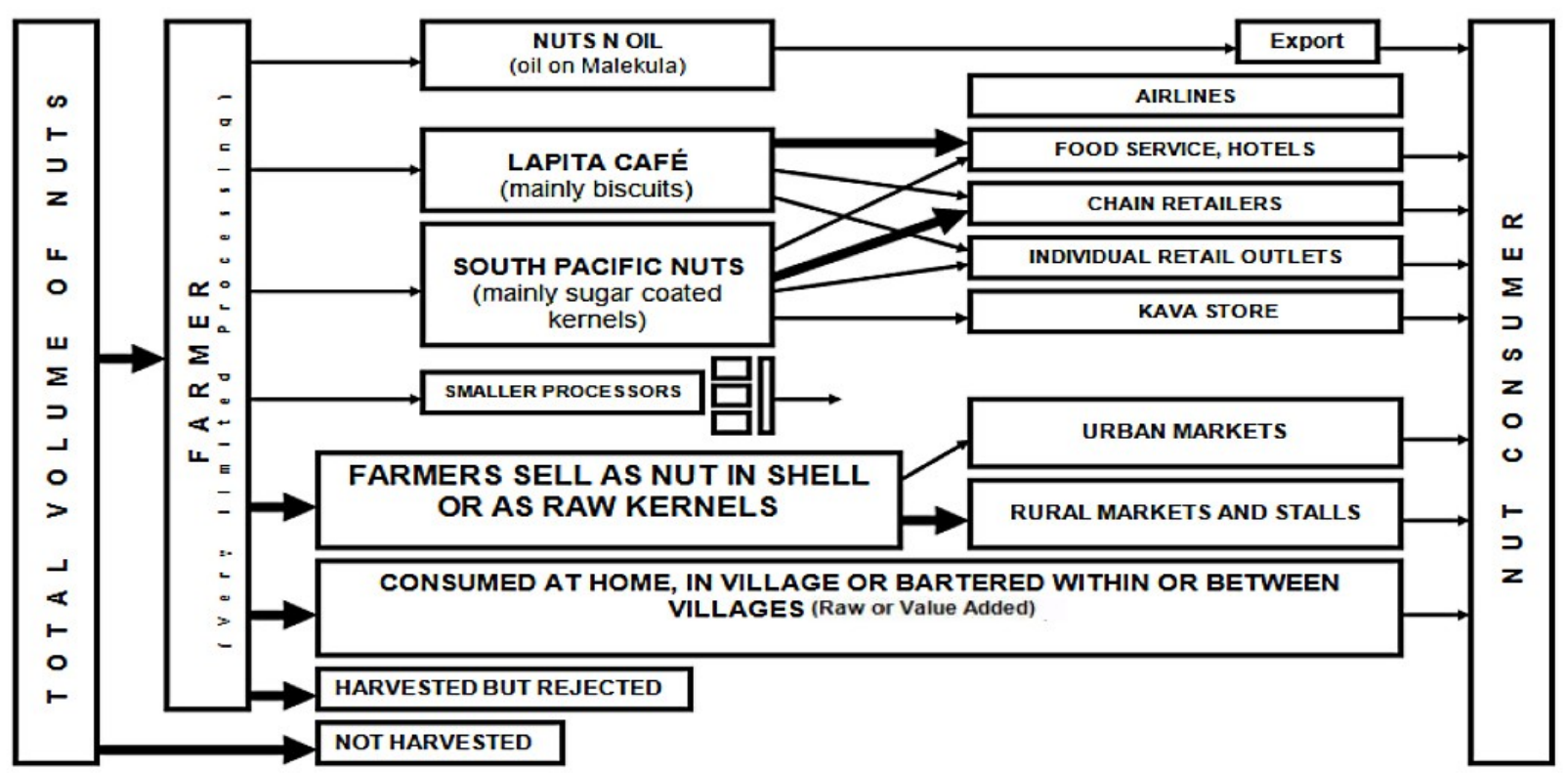

\subsection{Environmental Aspects of Forest Food Systems}

Forest food systems are low input systems not reliant on costly external inputs, which can be polluting and damaging to the environment. While a large part of global agricultural production takes place at the expense of biodiversity and the wider environment [88], forest food systems have a smaller ecological footprint: forests and trees are carbon sequestering [89], use fewer (or no) chemical inputs, and rely on natural precipitation instead of groundwater. The value of forest foods and other forest products, however, is often given inadequate attention when decisions are taken about land use planning.

A large body of scientific knowledge is being generated on the ecosystem services and environmental benefits provided by agroforestry systems, particularly carbon sequestration, biodiversity conservation, soil enrichment, air and water quality [90,91]. They supply also commodities as part of a multifunctional working landscape and contribute directly and indirectly to food security. Furthermore, agroforestry systems seem to be viable land use approaches for meeting the conflicting goals of agricultural production and environmental stewardship.

\section{Challenges and Opportunities to Strengthen the Role of Forest Foods in Sustainable Diets}

The concept of sustainable diets presented here is recent and its translation into an operational framework has not yet been implemented. The following sections present a series challenges and issues that should be addressed in order to strengthen the potential contribution of forest foods to sustainable diets. 


\subsection{Cultural Challenges}

One of the most widely reported factors likely to determine differences in the use and value of food tree products is ethnic traditions [92,93]. Traditional knowledge, intended as a cumulative body of knowledge and practices embedded in the cultural traditions of regional, indigenous, or local communities, should therefore be taken into consideration when promoting nutritious forest foods as part of diets, and in the selection of priority species for marketing and domestication.

Many indigenous people, including those living in forested environments, often face discrimination and marginalization, which can affect access to their traditional resources and collecting grounds, with potentially severe negative impacts on nutrition and health [94]. In addition to reduced access, the perception of indigenous foods, valued in the past, as old-fashioned or inferior can discourage their consumption. Other reasons for declining use [95,96], depending on the context, include: physical shortage of the product as a consequence of resource depletion, reduced time to gather wild foods as a result of changes in the availability or allocation of a household's supply of labor, increasing pressure on women's time, loss of knowledge about use of forest foods [97], and limited opportunities to commercialize production $[62,98]$.

Changes in livelihood strategies and the process of urbanization, coupled with the commercialization of food and changes in diets towards high salt and energy density, but with poor nutritional quality [99] have resulted in considerable modification in consumption and in natural resource use patterns.

\subsection{Sustainable Use of NWFPs and Threats to the Resource Base}

Several threats to forests and other tree-based systems could curtail their capacity to provide food and nutrients. Sustainability of NWFP use, including forest foods, depends greatly on level of use and the population dynamics of the species [68,100]. A review of fruit species important for the local economy and diet, regularly consumed in the region surrounding Iquitos, Peru [101], revealed that out of 193 fruit species used, 120 were exclusively wild-harvested and 19 additional species originated from both wild and cultivated sources. However, the availability of several of the most popular fruit species had decreased markedly. Furthermore, destructive harvesting techniques and increasing market pressures were rapidly depleting wild populations [102,103].

Conflict between different uses of trees for timber and NWFP can pose additional threats. In the Congo Basin, timber exploitation is placing growing pressure on local biodiversity, with potential negative repercussions on food security and livelihoods [104]. Some timber species have edible fruits and oil extracted from seeds; others host caterpillars that make up $75 \%$ of the protein eaten by the Baka during the period when caterpillars are available [105]. Examples of conflicts between multiple uses are also documented in Asia [106] and South America [107].

For several wild edible plant species there is still limited knowledge available regarding the effect that collection has on the genetic diversity and long-term survival of species' populations (see the case of Gnetum spp. [108,109]). In West Africa, when woodland is cleared for traditional agriculture, some selected multipurpose trees - supplying food, wood and medicinal functions - are maintained [110]. However, useful trees and shrubs are progressively disappearing, due to shortening fallow periods, 
tenure issues, drier climate, browsing by livestock and the absence of conservation practices to protect regeneration [111-113].

Overexploitation of certain wild animal populations is leading - depending on habitat, species, and hunting methods - to the extinction of some species with high vulnerability to hunting [114]. The resulting "bushmeat crisis" [37] is threatening the food security and livelihoods of some forest communities [27], especially where home consumption is more common than bushmeat trading. Sustainable harvest techniques for NWFPs of interest should be developed, optimal exploitation levels defined, and commercialization regulated.

\subsection{Challenges in Organizing Forest Food Provisioning}

The realization of the full potential for a sustainable commercialization of forest foods is limited by a number of issues. Forest foods are mostly consumed locally or traded in local or regional markets, with transport distances highly constrained by the perishability of products and pest infestation [115]. In addition, many forest food markets are not organized [116], usually not regulated by institutions, characterized by an unstructured flow of information about prices and product availability, by a small-scale, seasonal supply of produce, and the lack of credit facilities. Finally, the lack of scientific knowledge on resource availability and use potential, as well as on harvesting and transformation techniques, is further hampering the commercialization of forest foods [117].

Nonetheless, international markets exist for some forest food products; some examples are products derived from Gnetum africanum Welw., Cola acuminata (P.Beauv.) Schott \& Endl., Garcinia kola Heckel, Piper guineensis Schumach, Euterpe edulis Mart., Euterpe oleracea Mart., Euterpe precatoria Mart., Bertholletia excelsa H.B.K, Vitellaria paradoxa C. F. Gaertn, Pouteria sapota (Jacq.) H.E. Moore \& Stearn, Canarium indicum L.. In some cases these markets are growing due to an increasing demand linked to large presence of immigrants in Europe and the USA [117,118].

A case of successful promotion of sustainable trade is represented by PhytoTrade Africa, the commercial name used by the Southern African Natural Products Trade Association, a membershipbased organization established in 2001 to promote linkages between producers of NWFPs and global markets [119]. PhytoTrade Africa focuses on building value chains for a large variety of products, trying to ensure a reliable and efficient supply chain configuration, from primary producers to commercial partners. The products promoted by PhytoTrade include the following: pulp from the baobab (Adansonia digitata L.) fruit, used in healthy cereal bars and drinks, mainly because of its vitamin C content; and marula oil, extracted from the kernel of Sclerocarya birrea Hochst., highly appreciated in cosmetics because of its nourishing and moisturizing properties. The bark of the marula tree is said to be effective against diarrhea, dysentery, fever and malaria, and the fruit is used to make jam and beer. Other products promoted are the kigelia tree, common throughout Africa and whose oil and seeds have long been known for their dietary and medicinal properties, particularly in treating skin ailments; mongongo oil (from Ricinodendron rautanenii Schinz), extracted from mongongo nuts, a staple food of the bushmen of Botswana and Namibia; the oil from mafura (Trichilia emetica Vahl.) and ximenia (Ximenia americana L.) seeds.

The analysis of successful cases of forest-food value chain development in Cameroon, involving indigenous tree species, such as Ricinodendron heudelottii (Baill.) Pierre, Dacryodes edulis (G.Don) 
and Irvingia gabonensis (Aubrey-Lecomte ex O'Rorke) Baill., showed that domestication of indigenous tree species should be conceived together with value chains to obtain tangible positive impacts [48,119-121]. The incentives for domestication of indigenous trees depend on whether farmers can sell their produce in new or expanded markets. Participatory domestication approaches allow to keep poorer households involved all along the process of market development, and to ensure that they fully capture the benefits generated [122].

The creation and empowerment of legally registered associations at all levels (producers, transporters, wholesalers, retailers and consumers) is a necessary condition for successful development of NWFP markets for poverty alleviation and livelihood improvement [123,124]. Finally, consumer preferences should be studied and nutritional education organized to create and sustain local demand for forest foods.

\subsection{Relying More on Food-Based Approaches}

The roles of micronutrients in health and well-being and the synergies with the physiological functions of nutrients have been recognized [125,126]. Nutrition interventions should thus focus on improving overall diet quality. This calls for dietary diversification and food-based nutritional interventions [125,127,128]. Dietary diversity is defined as the number of unique food categories consumed over a given period of time, and functions as an indicator of food security [129] and a proxy for diet quality [130,131]. This measure allows researchers to better capture the whole-diet approach in a quick and low-cost manner. Translating this approach into programs is challenging, however, and researchers are investigating the best assessment tools for evaluating diversity in diets and nutritional outcomes [125,132-135].

Interest is growing in using micronutrient-rich foods, including food from indigenous or traditional trees and plants, to meet the high nutrient needs of infants and children, as their diets are based predominantly on staples [136]. Locally available and easily accessible, underused complementary foods may be affordable and potentially more acceptable than other options, such as supplementation and fortification. An example is the fermented condiment obtained from the seeds of Parkia biglobosa (Jacq.) R.Br. ex G.Don, in West Africa, called 'soumbala'. Soumbala is a rich source of iron $(16.9 \mathrm{mg} / 100 \mathrm{kcal})$ [137] and is often used as a low-cost meat substitute by families [138]. In addition, the bioavailability of nutrients varies and depends on what other foods are being eaten [139].

\subsection{Increasing Knowledge on Forest Foods}

There is possibility to increase the use and consumption of diverse foods, including traditional forest foods by enhancing the knowledge of policymakers, health care workers, and extension agents through provision of information [140,141]. Nutritional education activities that promote consumption of forest foods should be based on sound scientific knowledge of their nutritional values, and should be able to stimulate local positive attitudes towards wild edible plants [62]. Promoting the necessary behavior change to use and consume what are often considered inferior foods remains one of the biggest challenges due to the growing aversion to consuming certain traditional complementary foods (e.g., insects [142,143]). 
Food composition tables should be expanded to integrate more local food biodiversity. Some actions have already been taken in this respect [144,145]. Generation and use of better composition data for forest foods can be combined with research on ecology, management and (participatory) domestication so that appropriate nutritionally-rich species can be integrated into fields and home gardens [146]. Examples of increased consumption of micronutrient-rich foods as a result of information dissemination and promotion are available [147] and such an approach should be adopted for forest foods.

Nevertheless, nutrition interventions remain complicated by measurement issues and limited understanding of the actual requirements of many micronutrients. In addition, many factors beyond food quality influence nutritional status; such as the circumstances under which people consume food; their health, sanitation environment, cultural practices, etc. [148]. These factors affect project implementation and confound outcomes of programs aimed at promoting agrobiodiversity for better nutrition and health. Thus, a combined livelihood, agriculture, health, and education approach is necessary for improving nutritional status.

\subsection{Adapting Management of Forests and Trees to Account for Forest Foods}

Many traditional communities actively manage the wild resources they use and, in many cases, customary methods of resource management may be fundamental to the sustainable conservation of habitats and species [149-151].

In cases of conflict over the use of multipurpose species, which supply both timber and food products, forest management plans should be negotiated with timber concessions and adapted to consider the interests of both local communities and timber companies [105]. Such an approach should be based on a sound cost-benefit analysis that takes into account livelihoods and the food and nutritional benefits of forest foods in the diets of the local community.

Furthermore, nutritionally important indigenous trees can be introduced into farming systems through processes of domestication, in order to produce traditional forest foods, increase quality and yield, diversify the farming systems, strengthen its resilience and improve livelihoods [152].

According to priority-setting exercises conducted with farmers [7,110], several indigenous fruit tree species have large potential to improve livelihoods and nutrition of local people and rank highly for domestication and promotion through cultivation [7]; examples are Adansonia digitata L., Dacryodes edulis (G.Don), Sclerocarya birrea Hochst. and Uapaca kirkiana Müll.Arg. Wild and cultivated fruit tree species are largely represented in home gardens, which are complex and diverse types of agroforestry systems, maintained by household members mostly for subsistence production, found in many tropical regions, and supplying produce to an estimated 1 billion people [27]. They are constituted by a plot of land surrounding a homestead, and present a mixture of annual and perennial plant species arranged in a multi-layered vertical structure, often in combination with livestock [153]. They generally serve as a complement to staple crop fields by producing a variety of nutritious food products, including fruits and vegetables from cultivated and wild forest species [153]. It has been argued that home garden interventions can be highly effective for improving micronutrient intake [3,154]. In rural Nepal, a higher fruit and vegetable consumption was observed within households involved in a program targeting an increased production and consumption of annual and perennial home garden 
plant species, rich in vitamin A and iron [155]; this is expected to have positive impacts on children's nutritional status.

For most rural communities in sub-Saharan Africa, seasonality of fruit ripening, poor storage and processing are important causes of the low availability and consumption of fruits (see a review of main constraints in Jamnadass et al. [7]). Based on information and nutritional content of the specific fruits (focusing on the major micronutrients such as vitamins $\mathrm{A}$ and $\mathrm{C}$ and iron), site-specific fruit tree portfolios that provide fruits all year round could be developed and tested [47]. In addition, technologies to improve processing practices could improve availability [156,157].

Finally, women have a central role in ensuring food security and adequate nutrition [158,159]. The food security literature indicates that interventions directed towards women are likely to have a particularly beneficial impact [160]. Supporting the role of women as producers and consumers may help to remove barriers to improved nutrition and to enhance consumption of forest foods.

\subsection{Access Rights to Forest Foods}

A lack of secure access rights and land tenure discourages many poor or marginalized communities from investing in more productive land management, and from protecting and planting key species, which could play a key role in terms of food security and nutrition as in the case of parklands in West Africa [161,162]. Access by the poor to resources that can yield forest foods and income is still widely constrained by weak and ineffective political and institutional arrangements, affecting local control and management of forests. Policies and programs that enable local people to have a genuine role in decision-making are rare [163].

Community biodiversity management is an approach to natural resource management that contributes to the empowerment of agricultural and forest communities to better manage their biological resources, and to make informed decisions on the conservation and use of biodiversity including forest and tree resources [164]. Steps involved in community biodiversity management include: the introduction and domestication of wild species in home gardens; the creation of network of extension agents and community members; social institutional empowerment (land tenure rights); generation of livelihood benefits and income through consumption and sale of tree products.

\subsection{Integrating Forest Biodiversity into Complex Landscapes Managed for Multiple Benefits}

The diversity of foods that can be derived from different land uses, such as forest, fallow and agricultural margins, could help to provide the range of micronutrients needed for a sustainable human diet $[165,166]$. Forest fallows can be as productive of forest foods as pristine forests [167]. In many contexts, fallow land and farm bush areas are actively managed to protect and regenerate species of value to local communities. Examples include the babaçu palm (Attalea speciosa Mart. ex Spreng.) in northeast Brazil, which is integrated into local farmers' shifting cultivation systems [168], and fruit trees planted at an early stage in agricultural settlements [169]. Research and development practitioners must start thinking about ways to develop innovative roles for agro-ecosystems and heterogeneous landscapes, so as to ensure that food production systems and value chains are more nutrition-sensitive, while minimizing their ecological footprint [1]. 


\section{General Recommendations}

The following priority actions emerge from the review presented:

1. Prioritize research that examines the relative contribution of forest foods to local diets and nutrition, including analysis and documentation of their nutritional composition, digestibility and bioavailability, the effect of storage and processing on the nutritional value of specific forest foods, and the potential for domestication and integration of important tree species into value chains.

2. Describe and measure the sustainability of diets reliant on forest foods in relation to indigenous peoples' food systems, and compare these systems in terms of resilience, health, cost-effectiveness and sustainability with other diets and food systems across countries and regions.

3. Support research on governance and access issues and on the development of nutrition-sensitive value chains involving forest foods, with a particular focus on improving understanding of the risks associated with potential overharvesting and changes to access, as targeted NWFPs become more valuable.

4. Ensure extension services, NGOs, schools, hospitals and health centers are aware of the benefits and promote the consumption of nutritious forest foods within their programs and interventions, including efforts to counter negative perceptions and attitudes to local, traditional foods.

5. Promote a better integration of information and knowledge on nutritious forest foods and their conservation into national nutrition strategies and programs by establishing cross-sectoral policy platforms that bring together environment, health, development, agriculture and other sectors. These platforms would enable to better mainstream the use of tree biodiversity with high nutritional value into strategies addressing food security, nutrition, conservation, and land use planning and policy.

\section{Acknowledgements}

This paper was originally conceived as a background paper for the FAO conference on "Forests, food security and Nutrition" (13-15 May 2013). It has been substantially modified and expanded. Its preparation was supported by the CGIAR research programs on "Forests, Trees and Agroforestry" (CRP6) and "Agriculture for Nutrition and Health" (CRP4), and by the global GEF/UNEP/FAO project "Biodiversity for Food and Nutrition", led by Bioversity International. The authors thank Matthias Jager and Bhuwon Sthapit for supplying useful information, Ian Dawson and Bruce Cogill for their comments on an earlier version of the manuscript, Arwen Bailey for editorial review, and the reviewers of the current version for their useful feedback. Finally, thanks go to Denis Lairon, Aix Marseille Université, France, for permission to reprint the diagram in Figure 1, to Professor Steven Underhill, PARDI Project Leader, QAAFI, The University of Queensland, Australia and Professor Bill Aalbersberg, Director, Institute of Applied Sciences, University of the South Pacific, Fiji for their permission to reprint tables and diagrams included in Figure 3.

\section{Conflicts of interest}

The authors declare no conflict of interest 


\section{References}

1. Hunter, D.; Fanzo, J. Agricultural Biodiversity, Diverse Diets and Improving Nutrition. In Diversifying Food and Diets: Using Agricultural Biodiversity to Improve Nutrition and Health; Fanzo, J., Hunter, D., Borelli, T., Mattei, F., Eds.; Earthscan: London, UK, 2013; pp. 1-14.

2. Stephenson, K.; Amthor, R.; Mallowa, S.; Nungo, R.; Maziya-Dixon, B.; Gichuki, S.; Mbanaso, A.; Manary, M. Consuming cassava as a staple food places children 2-5 years old at risk for inadequate protein intake, an observational study in Kenya and Nigeria. Nutr. J. 2010, doi: 10.1186/1475-2891-9-9.

3. Tontisirin, K.; Nantel, G.; Bhattacharjee, L. Food-based strategies to meet the challenges of micronutrient malnutrition in the developing world. Proc. Nutr. Soc. 2002, 61, 243-250.

4. Johns, T.; Sthapit, B.R. Biocultural diversity in the sustainability of developing-country food systems. Food Nutr. Bull. 2004, 25, 143-155.

5. Johns, T.; Powell, B.; Maundu, P.; Eyzaguirre, P.B. Agricultural biodiversity as a link between traditional food systems and contemporary development, social integrity and ecological health. J. Sci. Food Agr. 2013, 93, 3433-3442.

6. Sunderland, T.C.H. Food security: Why is biodiversity important? Int. For. Rev. 2011, 13, 265-274.

7. Jamnadass, R.H.; Dawson, I.K.; Franzel, S.; Leakey, R.R.B.; Mithöfer, D.; Akinnifesi, F.K.; Tchoundjeu, Z. Improving livelihoods and nutrition in sub-Saharan Africa through the promotion of indigenous and exotic fruit production in smallholders' agroforestry systems: A review. Int. For. Rev. 2011, 13, 338-354.

8. Vinceti, B.; Eyzaguirre, P.; Johns, T. The Nutritional Role of Forest Plant Foods for Rural Communities. In Human Health and Forests: A Global Overview of Issues, Practice and Policy; Colfer, C.J.P., Ed.; Earthscan: London, UK, 2008; Volume 12, pp. 63-96.

9. Arnold, M.; Powell, B.; Shanley, P.; Sunderland, T.C.H. Forests, biodiversity and food security. Int. For. Rev. 2011, 13, 259-264.

10. Hladik, C.M., Hladik, A., Linares, O., Oagezy, H., Semple, A., Hadley, M., Eds. Tropical Forests, People and Food: Biocultural Interactions and Applications to Development; UNESCO/Parthenon Publishing Group: Carnforth, UK, 1993.

11. Millennium Ecosystem Assessment. Ecosystems and Human Well-Being: Health Synthesis and Biodiversity Synthesis; World Health Organization (WHO), World Research Institute: Geneva, Switzerland, 2005.

12. Food and Agriculture Organization (FAO). Global Forest Resources Assessment 2010: Progress towards Sustainable Forest Management; FAO: Rome, Italy, 2010.

13. Food and Agriculture Organization (FAO). Global Forest Resources Assessment 2000; FAO: Rome, Italy, 2000.

14. Mery, G.; Katila, P.; Galloway, G.; Alfaro, R.I.; Kanninen, M.; Lobovikov, M.; Vario, J. Changes in Global Markets for Forest Products and Timberlands. In Forests and Society-Responding to Global Drivers of Change; IUFRO: Vienna, Austria, 2010; pp. 137-156.

15. Food and Agriculture Organization, Bioversity International. Sustainable Diets and Biodiversity; Burlingame, B., Dernini, S., Eds.; Food and Agriculture Organization and Bioversity International: Rome, Italy, 2012. 
16. Fanzo, J.; Cogill, B.; Mattei, F. Metrics of Sustainable Diets and Food Systems; Bioversity International: Rome, Italy, 2012.

17. Dansi, A.; Adjatin, A.; Adoukonou-Sagbadja, H.; Faladé, V.; Yedomonhan, H.; Odou, D.; Dossou, B. Traditional leafy vegetables and their use in the Benin Republic. Genet. Resour. Crop Evol. 2008, 55, 1239-1256.

18. Powell, B.; Hall, J.; Johns, T. Forest cover, use and dietary intake in the East Usambara Mountains, Tanzania. Int. For. Rev. 2011, 13, 305-324.

19. Bailey, R.C.; Head, G.; Jenike, M.; Owen, B.; Rechtman, R.; Zechenter, E. Hunting and gathering in tropical rain forest: Is it possible? Am. Anthropol. 1989, 91, 59-82.

20. Colfer, C.J.P. Human Health and Forests: Global Overview of Issues, Practice and Policy; Earthscan: London, UK, 2008.

21. Humphry, C.M.; Clegg, M.S.; Keen, C.L.; Grivetti, L.E. Food diversity and drought survival: The Hausa example. Int. J. Food Sci. Nutr. 1993, 44, 1-16.

22. Moreno-Black, G.; Somnasang, P. In times of plenty and times of scarcity: nondomesticated food in north-eastern Thailand. Ecol. Food Nutr. 2000, 38, 563-586.

23. Faye, M.; Weber, J.; Mounkoro, B.; Dakouo, J.M. Contribution of parkland trees to farmers' livelihoods: a case study from Mali. Dev. Pract. 2010, 20, 428-434.

24. Arnold, J. Managing ecosystems to enhance the food security of the rural poor: A situation analysis prepared for IUCN. Available online: http://intranet.iucn.org/webfiles/ftp/public/ ForumEvents/E1533/Final\%20Document/Situation\%20Analysis\%20Forests\%20and\%20Food\% 20Security\%20by\%20M\%20Arnold\%20FINAL\%20DRAFT\%2030.05.08.pdf (accessed on 18 October 2013).

25. Food and Agriculture Organization. Non-wood forest products in nutrition. Paper prepared for the FAO/GOI Expert Consultation on Non-Wood Forest Products, Yogyakarta, Indonesia, 17-27 January 1995; Food and Agriculture Organization: Rome, Italy, 1995. Available online: http://www.fao.org/docrep/v7540e/V7540e15.htm (accessed on 15 October 2013).

26. Scoones, I.; Melnyk, M.; Pretty, J. The Hidden Harvest. Wild Foods and Agricultural Systems: A Literature Review and Annotated Bibliography; International Institute for Environment and Development (IIED)/SIDA and WWF International: London, UK, 1992.

27. Heywood, V. Overview of agricultural biodiversity and its contribution to nutrition and health. In Diversifying Food and Diets: Using Agricultural Biodiversity to Improve Nutrition and Health; Fanzo, J., Hunter, D., Borelli, T., Mattei, F., Eds.; Earthscan: London, UK, 2013; pp. 35-67.

28. Penafiel, D.; Lachat, C.; Espinel, R.; van Damme, P.; Kolsteren, P. A systematic review on the contributions of edible plant and animal biodiversity to human diets. EcoHealth 2011, 8, 381-399.

29. United Nations Standing Committee on Nutrition. 5th Report on the World Nutrition Situation; Standing Committee on Nutrition and International Food Policy Research Institute: Geneva, Switzerland, 2004.

30. Black, R.E.; Morris, S.S.; Bryce, J. Where and why are 10 million children dying every year? Lancet 2003, 361, 2226-2234.

31. Kennedy, G.; Nantel, G.; Shetty, P. The scourge of "hidden hunger": Global dimensions of micronutrient deficiencies. Food Nutr. Agric. 2003, 32, 8-16. 
32. Underwood, B.A. Vitamin A deficiency disorders: international efforts to control a preventable "pox". J. Nutr. 2004, 134, 231S-236S.

33. Smith, I.F.; Eyzaguirre, P.B. African leafy vegetables: their role in the world health organization's global fruit and vegetables initiative. Afr. J. Food Agric. Nutr. Dev. 2007, 7, 1-17.

34. Van Rensburg, W.J.; Venter, S.L.; Netshiluvhi, T.R.; van den Heever, E.; Vorster, H.J.; de Ronde, J.A. Role of indigenous leafy vegetables in combating hunger and malnutrition. S. Afr. J. Bot. 2004, 70, 52-59.

35. Misra, S.; Maikhuri, R.; Kala, C.; Rao, K.; Saxena, K. Wild leafy vegetables: A study of their subsistence dietetic support to the inhabitants of Nanda Devi Biosphere Reserve, India. J. Ethnobiol. Ethnomed. 2008, doi:10.1186/1746-4269-4-15.

36. Belem, B.; Sane, B.; Ouattara, E.; Sama, P.; Boussim, J. Wild leafy vegetables in the community of Séguénéga, northern Burkina Faso and their contribution to food security and income generation. Acta Hortic. (ISHS) 2009, 806, 121-128.

37. Nasi, R.; Brown, D.; Wilkie, D.; Bennett, E.; Tutin, C.; van Tol, G.; Christophersen, T. Conservation and Use of Wildlife-Based Resources: The Bushmeat Crisis; Technical Series No. 33; Secretariat of the Convention on Biological Diversity, Montreal, and Center for International Forestry Research (CIFOR): Bogor, Indonesia, 2008; p. 50.

38. Biesalski, H.-K. Meat as a component of a healthy diet - are there any risks or benefits if meat is avoided in the diet? Meat Sci. 2005, 70, 509-524.

39. Allen, L. To what extent can food-based approaches improve micronutrient status? Asia Pac. J. Clin. Nutr. 2008, 17, 103-105.

40. Golden, C.D.; Fernald, L.C.H.; Brashares, J.S.; Rasolofoniaina, B.J.R.; Kremen, C. Benefits of wildlife consumption to child nutrition in a biodiversity hotspot. Proc. Natl. Acad. Sci. USA 2011, 108, 19653-19656.

41. Toledo, Á.; Burlingame, B. Biodiversity and nutrition: A common path toward global food security and sustainable development. J. Food Compos. Anal. 2006, 19, 477-483.

42. Lutaladio, N.; Burlingame, B.; Crews, J. Horticulture, biodiversity and nutrition. J. Food Compos. Anal. 2010, 23, 481-485.

43. Bélanger, J.; Johns, T. Biological diversity, dietary diversity, and eye health in developing country populations: establishing the evidence-base. EcoHealth 2008, 5, 244-256.

44. Johns, T.; Eyzaguirre, P.B. Linking biodiversity, diet and health in policy and practice. Proc. Nutr. Soc. 2006, 65, 182-189.

45. HarvestPlus Nutrients. Available online: www.harvestplus.org/content/nutrients (accessed on 17 June 2013).

46. Ruel, M.; Minot, N.; Smith, L. Patterns and Determinants of Fruit and Vegetable Consumption in Sub-Saharan Africa; WHO: Kobe, Japan, 2005.

47. Kehlenbeck, K.; Asaah, E.; Jamnadass, R.H. Diversity of indigenous fruit trees and their contribution to nutrition and livelihoods in sub-Saharan Africa: Examples from Kenya and Cameroon. In Diversifying Food and Diets: Using Agricultural Biodiversity to Improve Nutrition and Health; Fanzo, J., Hunter, D., Borelli, T., Mattei, F., Eds.; Earthscan: London, UK, 2013; pp. 257-269. 
48. Leakey, R.R.B. Potential for novel food products from agroforestry trees: A review. Food Chem. 1999, 66, 1-14.

49. Stadlmayr, B.; Charrondiere, U.R.; Enujiugha, V.N.; Bayili, R.G.; Fagbohoun, E.G.; Samb, B.; Addy, P.; Barikmo, I.; Ouattara, F.; Oshaug, A.; et al. West African Food Composition Table; Food and Agriculture Organization: Rome, Italy, 2012; p. 173.

50. Stadlmayr, B.; Charrondiere, R.; Eisenwagen, S.; Jamnadass, R.H.; Kehlenbeck, K. Nutrient composition of selected indigenous fruits from sub-Saharan Africa. J. Sci. Food Agr. 2013, 93, 2627-2636.

51. Colfer, C.J.P.; Sheil, D.; Kishi, M. Forests and Human Health Assessing the Evidence; CIFOR Occasional Paper No. 45; CIFOR: Bogor, Indonesia, 2006.

52. Leakey, R.; Fuller, S.; Treloar, T.; Stevenson, L.; Hunter, D.; Nevenimo, T.; Binifa, J.; Moxon, J. Characterization of tree-to-tree variation in morphological, nutritional and medicinal properties of Canarium indicum nuts. Agroforest. Syst. 2007, 73, 77-87.

53. Graefe, S.; Dufour, D.; Zonneveld, M.; Rodriguez, F.; Gonzalez, A. Peach palm (Bactris gasipaes) in tropical Latin America: implications for biodiversity conservation, natural resource management and human nutrition. Biodivers. Conserv. 2012, 22, 269-300.

54. Leakey, R. Domestication potential of Marula (Sclerocarya birrea subsp. caffra) in South Africa and Namibia: 3. Multiple trait selection. Agroforest. Syst. 2005, 64, 51-59.

55. Leakey, R.; Schreckenberg, K.; Tchoundjeu, Z. The participatory domestication of West African indigenous fruits 1. Int. For. Rev. 2003, 5, 338-347.

56. United Nations Educational, Scientific and Cultural Organization. Convention for the Safeguarding of the Intangible Cultural Heritage; UNESCO: Paris, France, 2003.

57. Chweya, J.A., Eyzaguirre, P.B., Eds. The Biodiversity of Traditional Leafy Vegetables; International Plant Genetic Resources Institute: Rome, Italy, 1999; p. 182.

58. Macia, M.J. Multiplicity in palm uses by the Huaorani of Amazonian Ecuador. Bot. J. Linn. Soc. 2004, 144, 149-159.

59. Ndam, N.; Nkefor, P.; Blackmore, P. Domestication of Gnetum africanum and G. buchholzianum (Gnetaceae), over-exploited wild forest vegetables of the Central African Region. Syst. Geogr. Plants 2001, 71, 739-745.

60. Slikkerveer, L. Indigenous Agricultural Knowledge Systems in Developing Countries: A Bibliography; Leiden Ethnosystems and Development Programme (LEAD): Leiden, The Netherlands, 1994.

61. Shackleton, S.; Shanley, P.; Ndoye, O. Invisible but viable: recognising local markets for non- timber forest products. Int. For. Rev. 2007, 9, 697-712.

62. Kuhnlein, H.V.; Erasmus, B.; Spigelski, D. Indigenous Peoples' Food Systems: The Many Dimensions Of Culture, Diversity And Environment For Nutrition And Health; FAO: Rome, Italy, 2009; p. 339.

63. Kuhnlein, H.V.; Erasmus, B.; Spigelski, D.; Burlingame, B. Indigenous Peoples' Food Systems and Well-Being: Interventions and Policies for Healthy Communities; FAO: Rome, Italy, 2013; p. 398. 
64. Shepherd, A. The implications of supermarket development for horticultural farmers and traditional marketing systems in Asia. Paper presented to the FAO/AFMA/fama regional workshop on the growth of supermarkets as retailers of fresh produce, Kuala, Lumpur, Malaysia, 4-7 October 2004.

65. Wong, W.W.W. Good Practices of On-Farm Conservation of Tropical Fruit Tree Diversity in Malaysia. Paper Presented at International Good Practices Workshop; Bangkok, Thailand, 4-5 April, 2005. Available online: http://www.sabah.gov.my/tani/pdf/penyelidikan/Publication\%20 List\%20Research\%20Branch.pdf (accessed on 18 October 2013).

66. Kalitu, N.; Wong, W.W.W.; Chong, T.C. Indigenous fruits with potential for use as food crop. Indigenous Fruits with Potential for Use as Food Crop, Seminar on Food Crop Production in Sabah, Kota Kinabalu, Sabah, 8-9 October 2002.

67. Sthapit, B.; Sajise, P.; Rao, R.; Queck, P.; de Cruz, F.; Bellon, M. Selection of Good Practices of In Situ Conservation of Tropical Fruit Tree Species Diversity: Methodology and Key Practices; Appendix K of the GEF UNEP Bioversity Project "Conservation and Sustainable Use of Cultivated and Wild Tropical Fruit Diversity”; Bioversity: Rome, Italy, 2008.

68. Belcher, B.; Ruizperez, M.; Achdiawan, R. Global patterns and trends in the use and management of commercial NTFPs: Implications for livelihoods and conservation. World Dev. 2005, 33, 1435-1452.

69. Angelsen, A.; Wunder, S.; Babigumira, R.; Belcher, B.; Börner, J.; Smith-Hall, C. Environmental Incomes and Rural Livelihoods: A Global-Comparative Assessment; Brazilian Institute of Geography and Statistics/Food and Agricultural Organization: Paper presented at the 4th Wye Global Conference, Rio de Janeiro, country, 9-11 November 2011. Available online: http://www.fao.org/fileadmin/templates/ess/pages/rural/wye_city_group/2011/documents/session 4/Angelsen_Wunder_Babigumira_Belcher_Birner_Smith-Hall-Paper.pdf (accessed on 18 October 2013).

70. Ruiz-Pérez, M.; Belcher, B.; Achdiawan, R.; Alexiades, M.; Aubertin, C.; Campbell, B.; Clement, C.; Cunningham, T.; Fantini, A.; Foresta, H.D.; et al. Markets drive the specialization strategies of forest peoples. Available online: http:/www.ecologyandsociety.org/vo19/iss2/art4/ (accessed on 18 October 2013).

71. Marshall, D., Schreckenberg, K., Newton, A.C., Eds. Commercialization of Non-Timber Forest Produts: Factors Influencing Success. Lessons from Mexico and Bolivia and Policy Implications for Decision-Makers; UNEP World Monitoring Centre: Cambridge, UK, 2006.

72. Pimentel, D.; McNair, M.; Buck, L.; Pimentel, M.; Kamil, J. The value of forests to world food security. Hum. Ecol. 1997, 25, 91-120.

73. Shanley, P.; Luz, L.; Swingland, I.R. The faint promise of a distant market: a survey of Belém's trade in non-timber forest products. Biodivers. Conserv. 2002, 11, 615-636.

74. Belcher, B.; Schreckenberg, K. Commercialisation of non-timber forest products: A reality check. Dev. Policy Rev. 2007, 25, 355-377.

75. Shackleton, C.; Shackleton, S. The importance of non-timber forest products in rural livelihood security and as safety nets: a review of evidence from South Africa. S. Afr. J. Sci. 2004, 100, $658-664$. 
76. Delang, C.O. The role of wild food plants in poverty alleviation and biodiversity conservation in tropical countries. Prog. Dev. Stud. 2006, 6, 275-286.

77. Stoian, D. Making the Best of Two Worlds: Rural and Peri-Urban Livelihood Options Sustained by Nontimber Forest Products from the Bolivian Amazon. World Dev. 2005, 33, 1473-1490.

78. Kaimovitz, D. Not by bread alone... forests and rural livelihoods in sub-Saharan Africa. In Forestry in Poverty Reduction Strategies: Capturing the Potential; Oksanen, T., Pajari, B., Tuomasjukka, T., Eds.; European Forest Institute: Joensuu, Finland, 2003; pp. 45-64.

79. Termote, C.; Everaert, G.; Bwama Meyi, M.; Dhed'a Djailo, B.; Damme, P. Wild edible plant markets in Kisangani, Democratic Republic of Congo. Hum. Ecol. 2012, 40, 269-285.

80. Ndoye, O.; Ruiz Perez, M.; Eyebe, A. The markets of non-timber forest products in the humid forest zone of Cameroon. Available online: http://www.odi.org.uk/sites/odi.org.uk/files/odiassets/publications-opinion-files/1168.pdf (accessed on 18 October 2013).

81. Hawkes, C.; Ruel, M. Agriculture and nutrition linkages: Old lessons and new paradigms. In Reshaping Agriculture for Nutrition and Health; Fan, S., Pandya-Lorch, R., Eds.; IFPRI: Washington, DC, USA, 2006; pp. 73-82.

82. Von Braun, J.; Diaz-Bonilla, E. Globalization of agriculture and food: Causes, consequences and policy implications. In Globalization of Food and Agriculture and the Poor; von Braun, J., Diaz-Bonilla, E., Eds.; Oxford University Press: New Delhi, India, 2008.

83. Hawkes, C.; Ruel, M. Value chains for nutrition. In Reshaping Agriculture for Nutrition and Health; Fan, S., Pandya-Lorch, R., Eds.; IFPRI: Washington, DC, USA, 2012; pp. 73-82.

84. Evans, B.R. Overview of Resource Potential for Indigenous Nut Production in the South Pacific; Stevens, M.L., Bourke, R.M., Evans, B.R., Eds.; Austrialian Centre for International Agricultural Research (ACIAR): Canberra, Australia, 1996; pp. 10-35.

85. English, R.M.; Aalbersberg, W.G.L.; Scheelings, P. Pacific Islands Foods-Description and Nutrient Composition of 78 Local Food Samples; IAS Technical Report No. 96/02; University of the South Pacific: Suva, Fiji, 1996; p. 94.

86. Pacific Agribusiness Research \& Development Initiative (PARDI). AIARC Canarium Nut Value Chain Review. Available online: https://www.spc.int/lrd/index.php?option=com_docman\&task= doc_download\&gid=1627\&Itemid=575 (accessed on 15 October 2013).

87. Thomson, L.A.J.; Evans, B. Canarium indicum var. indicum and C. harveyi (canarium nut) ver 2.1. In Species Profiles for Pacific Island Agroforestry; Permanent Agriculture Resources (PAR): Holualoa, HI, USA, 2006.

88. McMichael, A.J. Integrating nutrition with ecology: balancing the health of humans and biosphere. Publ. Health Nutr. 2005, 8, 706-715.

89. Montagnini, F.; Nair, P.K.R. Carbon sequestration: An underexploited environmental benefit of agroforestry systems. Agroforest. Syst.2004, 61, 281-295.

90. Kang, B.T.; Akinnifesi, F.K. Agroforestry as alternative land-use production systems for the tropics. Nat. Resourc. Forum 2000, 24, 137-151.

91. Jose, S. Agroforestry for ecosystem services and environmental benefits: An overview. Agroforest. Syst. 2009, 76, 1-10. 
92. De Caluwe, E.; De Smedt, S.; Assogbadjo, A.E.; Samson, R.; Sinsin, B.; van Damme, P. Ethnic differences in use value and use patterns of baobab (Adansonia digitata L.) in northern Benin. Afr. J. Ecol. 2009, 433-440.

93. Termote, C.; Damme, P.; Dhed'a Djailo, B. Eating from the wild: Turumbu, Mbole and Bali traditional knowledge on non-cultivated edible plants, District Tshopo, DRCongo. Genet. Resour. Crop Evol. 2011, 58, 585-618.

94. Kuhnlein, H.V.; Receveur, O. Dietary change and traditional food systems of indigenous peoples. Annu. Rev. Nutr. 1996, 16, 417-442.

95. Lykke, A.M.; Mertz, O.L.E.; Ganaba, S. Food comsumption in rural Burkina Faso. Ecol. Food Nutr. 2002, 41, 119-153.

96. Keller, G.B.; Mndiga, H.; Maass, B.L. Diversity and genetic erosion of traditional vegetables in Tanzania from the farmer's point of view. Plant Gen. Resour. Char. Utili. 2005, 3, 400-413.

97. Falconer, J. The Major Significance of "Minor" Forest Products: The Local Use and Value of Forests in the West African Humid Forest Zone; FAO: Rome, Italy, 1990; FAO Community Forestry Note 6.

98. Bharucha, Z.; Pretty, J. The roles and values of wild foods in agricultural systems. Philos. Trans. R. Soc. B 2010, 365, 2913-2926.

99. Popkin, B.M. The nutrition transition: an overview of world patterns of change. Nutr. Rev. 2004, 62, S140-S143.

100. Ticktin, T. The ecological implications of harvesting non-timber forest products. J. Appl. Ecol. 2004, 41, 11-21.

101. Vasquez, R.; Gentry, A.H. Use and Misuse of Forest-harvested Fruits in the Iquitos Area. Conserv. Biol. 1989, 3, 350-361.

102. Delvaux, C.; Sinsin, B.; van Damme, P. Impact of season, stem diameter and intensity of debarking on survival and bark re-growth pattern of medicinal tree species, Benin, West Africa. Biol. Conserv. 2010, 143, 2664-2671.

103. Sundriyal, M.; Sundriyal, R.C. Wild Edible Plants of the Sikkim Himalaya: Marketing, Value Addition and Implications for Management. Econ. Bot. 2004, 58, 300-315.

104. Rist, L.; Shanley, P.; Sunderland, T.; Sheil, D.; Ndoye, O.; Liswanti, N.; Tieguhong, J. The impacts of selective logging on non-timber forest products of livelihood importance. Forest Ecol. Manag. 2012, 268, 57-69.

105. Ndoye, O.; Tieguhong, J.C. Forest Resources and Rural Livelihoods: The Conflict Between Timber and Non-timber Forest Products in the Congo Basin. Scand. J. For. Res. 2004, 19, 36-44.

106. Limberg, G.R.; Iwan, M.; Moeliono, M.; Sudana, I.M.; Wollenberg, E. Community-based forestry and management planning. In Managing forest resources in a decentralized environment: lessons learnt from the Malinau Research Forest, East Kalimantan; Gunarso, P., Setyawati, T., Sunderland, T., Shackleton, C., Eds.; CIFOR (Center for International Forestry Research): Bogor, Indonesia, 2007.

107. Guariguata, M.R.; García-Fernández, C.; Sheil, D.; Nasi, R.; Herrero-Jáuregui, C.; Cronkleton, P.; Ingram, V. Compatibility of timber and non-timber forest product management in natural tropical forests: Perspectives, challenges, and opportunities. For. Ecol. Manag. 2010, 259, 237-245. 
108. Ndoye, O.; Awono, A. Case Study B: policies for Gnetum spp. trade in Cameroon: overcoming constraints that reduce benefits and discourage sustainability. In Wild Governance: Finding Policies that Work for Non-Timber Forest Products; Laird, S.A., McLain, R.J., Wynberg, R.P., Eds.; Earthscan: London, UK, 2010; pp. 71-76.

109. Ingram, V.J.; Ndumbe, L.N.; Ewane, M.E. Small scale, high value: Gnetum africanum and Gnetum buchholzianum value chains in Cameroon. Small Scale For. 2012, 11, 539-556.

110. Faye, M.D.; Weber, J.C.; Abasse, T.A.; Boureima, M.; Larwanou, M.; Bationo, A.B.; Diallo, B.O.; Sigué, H.; Dakouo, J.M.; Samaké, O.; Diaité, D.S. Farmers' preferences for tree functions and species in the West African Sahel. For. Trees Livelihoods 2011, 20, 113-136.

111. Gijsbers, H.J.M.; Kessler, J.J.; Knevel, M.K. Dynamics and natural regeneration of woody species in farmed parklands in the Sahel region (province of Passore, Burkina-Faso). For. Ecol. Manag. 1994, 64, 1-12.

112. Nikiema, A. Agroforestry Parkland Species Diversity: Uses and Management in Semi-Arid West Africa (Burkina Faso). PhD Thesis, University of Wageningen, Wageningen, The Netherlands, 2005.

113. Maranz, S. Tree mortality in the African Sahel indicates an anthropogenic ecosystem displaced by climate change. J. Biogeogr. 2009, 36, 1181-1193.

114. Nasi, R.; Taber, A.; van Vliet, N. Empty forests, empty stomachs? Bushmeat and livelihoods in the Congo and Amazon Basins. Int. For. Rev. 2011, 13, 355-368.

115. Akinnifesi, F.K.; Kwesiga, F.; Mhango, J.; Chilanga, T.; Mkonda, A.; Kadzere, I.; Mithofer, D.; Sileshi, G.; Ramadhani, T.; Dhliwayo, P. Towards the development of Miombo fruit trees as commercial tree crops in Southern Africa. For. Trees Livelihoods 2006, 16, 103-121.

116. Koppell, C. Marketing Information Systems for Non-Timber Forest Products; FAO: Rome, Italy,1995; Community Forestry Field Manual 6, p. 115.

117. Bamoninga, B. Analyse de L'état de Lieux du Secteur des Produits Forestiers non Ligneux et Evaluation de Leur Contribution à la Sécurité Alimentaire en RDC (in French); FAO project GCP/RAF/398/GER; FAO: Rome, Italy, 2007.

118. Tabuna, H. Evaluation des Échanges des Produits Forestiers non Ligneux Entre l'Afrique Subsaharienne et l'Europe (in French); FAO: Rome, Italy, 2000.

119. Lombard, C.; Leakey, R.R.B. Protecting the rights of farmers and communities while securing long term market access for producers of non-timber forest products: Experience in Southern Africa. For. Trees Livelihoods 2010, 19, 235-249.

120. Leakey, R.R.B.; Izac, A.M.N. Linkages between domestication and commercialization of non-timber forest products: Implications for agroforestry. In Domestication and Commercialization of Non-Timber Forest Products; Leakey, R.; Temu, A.; Melnyk, M., Eds.; FAO: Rome, Italy, 1996; pp. $1-7$.

121. Tchoundjeu, Z.; Degrande, A.; Leakey, R.R.B.; Nimino, G.; Kemajou, E.; Asaah, E.; Facheux, C.; Mbile, P.; Mbosso, C.; Sado, T.; et al. Impacts of participatory tree domestication on farmer livelihoods in west and central Africa. For. Trees Livelihoods 2010, 19, 217-234.

122. Russell, D.; Franzel, S. Trees of prosperity: Agroforestry, markets and the African smallholder. Agroforest. Syst. 2004, 345-355.

123. Scherr, S.J.; White, A.; Kaimowitz, D. Making markets work for forest communities. Int. For. Rev. 2003, 5, 67-73. 
124. Gruère, G.; Giuliani, A.; Smale, M. Marketing Underutilized Plant Species for the Benefit of the Poor: A Conceptual Framework; Environment and Production Technology Discussion Paper 154; IFPRI: Washington, DC, USA, 2006.

125. Frison, E.; Smith, I.F.; Johns, T.; Cherfas, J.; Eyzaguirre, P. Agricultural biodiversity, nutrition, and health: Making a difference to hunger and nutrition in the developing world. Food Nutr. Bull. 2006, 27, 167-179.

126. Remans, R.; Flynn, D.F.B.; de Clerck, F.; Diru, W.; Fanzo, J.; Gaynor, K.; Lambrecht, I.; Mudiope, J.; Mutuo, P.K.; Nkhoma, P.; et al. Assessing nutritional diversity of cropping systems in African villages. PLoS ONE 2011, 6, e21235.

127. Torheim, L.E.; Ferguson, E.L.; Penrose, K.; Arimond, M. Women in resource-poor settings are at risk of inadequate intakes of multiple micronutrients. J. Nutr.2010, 140, 2051S-2058S.

128. Fanzo, J., Hunter, D., Borelli, T., Mattei, F., Eds. Diversifying Food and Diets: Using Agricultural Biodiversity to Improve Nutrition and Health; Earthscan: London, UK, 2013.

129. Hoddinott, J.; Yohannes, Y. Dietary Diversity as a Food Security Indicator. Dietary Diversity as a Household Food Security Indicator: Food and Nutrition Technical Assistance; Academy for Educational Development: Washington, DC, USA, 2002.

130. Arimond, M.; Wiesmann, D.; Becquey, E.; Carriquiry, A.; Daniels, M.C.; Deitchler, M.; Fanou-Fogny, N.; Joseph, M.L.; Kennedy, G.; Martin-Prevel, Y.; et al. Simple food group diversity indicators predict micronutrient adequacy of women's diets in 5 diverse, resource-poor settings. J. Nutr. 2010, 140, 2059S-2069S.

131. Ruel, M.T. Is dietary diversity an indicator of food security or dietary quality? A review of measurement issues and research needs. Food Nutr. Bull. 2003, 24, 231-232.

132. Kennedy, G.; Fanou-Fogny, N.; Seghieri, C.; Arimond, M.; Koreissi, Y.; Dossa, R.; Kok, F.J.; Brouwer, I.D. Food groups associated with a composite measure of probability of adequate intake of 11 micronutrients in the diets of women in urban Mali. J. Nutr. 2010, 140, 2070S-2078S.

133. Ruel, M.T. Operationalizing dietary diversity: A review of measurement issues and research priorities. J. Nutr. 2003, 133, 3911S-3926S.

134. Savy, M.; Martin-Prével, Y.; Sawadogo, P.; Kameli, Y.; Delpeuch, F. Use of variety/diversity scores for diet quality measurement: Relation with nutritional status of women in a rural area in Burkina Faso. Eur. J. Clin. Nutr. 2005, 59, 703-716.

135. Torheim, L.E.; Ouattara, F.; Diarra, M.M.; Thiam, F.D.; Barikmo, I.; Hatløy, A.; Oshaug, A. Nutrient adequacy and dietary diversity in rural Mali: Association and determinants. Eur. J. Clin. Nutr 2004, 58, 594-604.

136. Kuyper, E.; Vitta, B.; Dewey, K. Novel and underused food sources of key nutrients for complementary feeding. Available online: http://aliveandthrive.org/sites/default/files/ Issue $\% 206 \% 20$ Novel $\% 20$ and $\% 20$ underused $\% 20$ food $\% 20$ sournces $\% 20$ of $\% 20$ key $\% 20$ nutrients $\%$ 20 for\%20complementary\%20feeding_0.pdf (accessed on 14 June 2013).

137. Ouédraogo, H.Z.; Traoré, T.; Zèba, A.N.; Dramaix-Wilmet, M.; Hennart, P.; Donnen, P. Effect of an improved local ingredient-based complementary food fortified or not with iron and selected multiple micronutrients on Hb concentration. Publ. Health Nutr. 2010, 13, 1923-1930. 
138. Savadogo, A.; Ilboudo, A.J.; Gnankiné, O.; Traoré, A. Numeration and Identification of thermotolerant endospore-forming Bacillus from two fermented condiments Bikalga and Soumbala. Adv. Environ. Biol. 2011, 5, 2960-2966.

139. Parada, J.; Aguilera, J.M. Food microstructure affects the bioavailability of several nutrients. J. Food Sci. 2007, 72, 21-32.

140. Bisseleua, H.B.D.; Niang, A.I. Lessons from Sub-Saharan Africa: Delivery Mechanisms for Mobilizing Agricultural Biodiversity for Improved Food and Nutrition Security; Fanzo, J., Hunter, D., Borelli, T., Mattei, F., Eds.; Earthscan: London, UK, 2013; pp. 111-121.

141. Smith, I.F. Sustained and integrated promotion of local, traditional food systems for nutrition security. In Diversifying Food and Diets: Using Agricultural Biodiversity to Improve Nutrition and Health; Fanzo, J., Hunter, D., Borelli, T., Mattei, F., Eds.; Earthscan: London, UK, 2013; pp. 122-139.

142. De Foliart, G.R. Insects as food: Why the western attitude is important. Annu. Rev. Entomol. 1999, 44, 21-50.

143. Van Huis, A. Edible Insects: Future Prospects For Food And Feed Security; FAO: Rome, Italy, 2013.

144. Burlingame, B.; Charrondiere, R.; Mouille, B. Food composition is fundamental to the cross-cutting initiative on biodiversity for food and nutrition. J. Food Compos. Anal. 2009, 22, 361-365.

145. Nesbitt, M.; McBurney, R.P.H.; Broin, M.; Beentje, H.J. Linking biodiversity, food and nutrition: The importance of plant identification and nomenclature. J. Food Compos. Anal. 2010, 23, 486-498.

146. Pudasaini, R.; Sthapit, S.; Suwal, R.; Sthapit, B.R. The role of integrated home gardens and local, neglected and underutilized plant species in food security in Nepal and meeting the Millennium Development Goal 1 (MDG). In Diversifying Food and Diets: Using Agricultural Biodiversity to Improve Nutrition and Health; Fanzo, J., Hunter, D., Borelli, T., Mattei, F., Eds.; Earthscan: London, UK, 2013; pp. 242-256.

147. Low, J.W.; Arimond, M.; Osman, N.; Cunguara, B.; Zano, F.; Tschirley, D. A food-based approach introducing orange-fleshed sweet potatoes increased vitamin A intake and serum retinol concentrations in young children in rural Mozambique. J. Nutr. 2007, 137, 1320-1327.

148. Masset, E.; Haddad, L.; Cornelius, A.; Isaza-Castro, J. Effectiveness of agricultural interventions that aim to improve nutritional status of children: Systematic review. BMJ 2012, doi: 10.1136/bmj.d8222.

149. Schroeder, R.A. Shady Practice: Gender and the Political Ecology of Resource Stabilization in Gambian Garden/Orchards. Econ. Geogr. 1993, 69, 349-365.

150. Greenberg, L. Women in the garden and kitchen: the role of cuisine in the conservation of traditional house lot crops among the Yucatec Mayan immigrants. In Women and Plants: Gender Relations in Biodiversity Management and Conservation; Howard, P.L., Ed.; Zed Books Ltd.: London, UK, 2003.

151. Anderson, K. Tending the Wild: Native American Knowledge and the Management of California's Natural Resources; University of California Press: Berkeley, CA, USA, 2006. 
152. Garrity, D.P.; Akinnifesi, F.K.; Ajayi, O.C.; Weldesemayat, S.G.; Mowo, J.G.; Kalinganire, A.; Larwanou, M.; Bayala, J. Evergreen Agriculture: A robust approach to sustainable food security in Africa. Food Secur. 2010, 2, 197-214.

153. Kehlenbeck, K.; Arifin, H.; Maass, B. Plant diversity in homegardens in a socio-economic and agro-ecological context. In The Stability of Tropical Rainforest Margins: Linking Ecological, Economic and Social Constraints of Land Use and Conservation; Tscharntke, T., Leuschner, C., Zeller, M., Guhardja, E., Bidin, A., Eds.; Springer: Berlin, Germany, 2007; pp. 297-319.

154. Berti, P.R.; Krasevec, J.; FitzGerald, S. A review of the effectiveness of agriculture interventions in improving nutrition outcomes. Publ. Health Nutr. 2004, 7, 599-609.

155. Jones, K.M.; Specio, S.E.; Shrestha, P.; Brown, K.H.; Allen, L.H. Nutrition knowledge and practices, and consumption of vitamin A-rich plants by rural Nepali participants and nonparticipants in a kitchen-garden program. Food Nutr. Bull. 2005, 26, 198-208.

156. Kitinoja, L.; Kader, A. Small-Scale Postharvest Practices A Manual for Horticultural Crops-Postharvest Technology Center; University of California Davis: Davis, CA, USA, 2002.

157. Ogunsina, B.S.; Koya, O.A.; Adeosun, O.O.A Table Mounted Device for Cracking Dika Nut (Irvingia gabonensis). Available online: http://www.cigrjournal.org/index.php/Ejounral/article/ viewFile/1096/1039 (accessed on 17 September 2013).

158. Ibnouf, F.O. The role of women in providing and improving household food security in sudan: Implications for reducing hunger and malnutrition. J. Int. Womens Stud. 2009, 10, 144-167.

159. De Schutter, O. Report submitted by the UN Special Rapporteur on the right to food to the UN General Assembly Human Rights Council. Available online: http://www.srfood.org/ images/stories/pdf/officialreports/20110308_a-hrc-16-49_agroecology_en.pdf (accessed on 12 October 2013).

160. Hoddinott, J. Operationalizing Household Food Security in Development Projects: An Introduction; IFPRI (International Food Policy Research Institute): Washington, DC, USA, 1999.

161. Teklehaimanot, Z. Exploiting the potential of indigenous agroforestry trees: Parkia biglobosa and Vitellaria paradoxa in sub-Saharan Africa. Agroforest. Syst. 2004, 61-62, 207-220.

162. Ræbild, A.; Hansen, U.B.; Kambou, S. Regeneration of Vitellaria paradoxa and Parkia biglobosa in a parkland in Southern Burkina Faso. Agroforest. Syst. 2011, 85, 443-453.

163. Larson, A.M.; Ribot, J.C. The poverty of forestry policy: double standards on an uneven playing field. Sustain. Sci. 2007, 2, 189-204.

164. De Boef, W.S.; Subedi, A.; Peroni, N.; Thijssen, M. Community Biodiversity Management: Promoting Resilience and the Conservation of Plant Genetic Resources; Earthscan: London, UK, 2013.

165. High, C.; Shackleton, C.M. The comparative value of wild and domestic plants in home gardens of a south African rural village. Agroforest. Syst. 2000, 48, 141-156.

166. Padoch, C.; Pinedo-Vasquez, M. Saving Slash-and-Burn to Save Biodiversity. Biotropica 2010, 42, 550-552.

167. Davies, A.G.; Richards, P. Rain Forest in Mende Life: Resources and Subsistence Strategies in Rural Communities around the Gola North Forest Reserve (Sierra Leone); A Report to ESCOR; Overseas Development Administration: London; UK, 1991. 
168. May, P.H.; Anderson, A.B.; Frazão, J.M.F.; Balick, M.J. Babassu palm in the agroforestry systems in Brazil's mid-north region. Agroforest. Syst. 1985, 3, 275-295.

169. Arnold, J.E.M.; Dewees, P.A. Farms, Trees and Farmers: Responses to Agricultural Intensification; Earthscan: London, UK, 1997; Volume 20, pp. 328-329.

(C) 2013 by the authors; licensee MDPI, Basel, Switzerland. This article is an open access article distributed under the terms and conditions of the Creative Commons Attribution license (http://creativecommons.org/licenses/by/3.0/). 